$\langle$ Back to results $| 1$ of 2 Next >

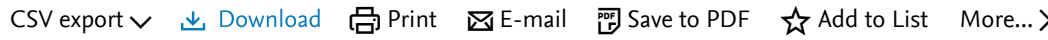

Full Text |View at Publisher|

Document type

Conference Paper

Source type

Conference Proceedings

ISSN

22147853

DOI

10.1016/j.matpr.2021.02.361

View more $\checkmark$

Materials Today: Proceedings • Volume 46, Pages 2673 - 2676 • 2021 • 2nd International Conference on Smart and Sustainable Developments in Materials, Manufacturing and Energy Engineering, SME 2020 • Nitte • 22 December 2020 through 23 December 2020 • Code 170455

\section{Estimation of Mach numbers in supersonic jets using schlieren images}

Faheem M. ${ }^{a, c}, \quad$ Khan A. $^{b}, \quad$ Kumar R. ${ }^{b}, \quad$ Khan S.A. ${ }^{a}$ 更, Asrar W. ${ }^{a}, \quad$ Azan Mohammed Sapardi M. ${ }^{a}$

国 Save all to author list

a Department of Mechanical Engineering, Faculty of Engineering, International Islamic University Malaysia, Kuala Lumpur, Malaysia ${ }^{b}$ Department of Aerospace Engineering, Indian Institute of Technology, Uttar Pradesh, Kanpur, India

${ }^{\mathrm{c}}$ Department of Mechanical Engineering, P.A College of Engineering (Affiliated to VTU Belagavi), Karnataka, Mangaluru, India

\section{1}

Citation in Scopus

$$
\text { View all metrics > }
$$

\section{Abstract}

Author keywords

SciVal Topics

Metrics

Abstract

Supersonic nozzles are commonly used in mechanical and aerospace engineering applications for decades. Therefore, it is essential to study their characteristics and discover techniques to measure relevant flow properties with minimal investment in terms of time, money, and efforts. Supersonic jets are composed of shock waves and expansion waves, making the flowfield complex and difficult to probe and investigate. Some important parameters that are needed to understand the supersonic jet include the shock-cell orientation and the variation of the Mach number along the jet centerline. Expensive equipment and highly skilled manpower are needed to get this information both in the lab environment and in real applications. A simple yet effective approach is presented in the present work to get reasonable estimates of the Mach number from the schlieren images for a Mach 2.0 nozzle jet. Results are compared with the numerical simulations for the estimated Mach number from the experimental data. (c) 2021 Elsevier Ltd. All rights reserved.

Author keywords

Image processing; Numerical simulations; Pixel intensity; Schlieren; Supersonic Jet

\section{Cited by 1 document}

Experimental investigation of the effect of cross wire on the flow field of elliptic jet

Faheem, M., Khan, A. , Kumar, R. (2021) International Journal of Heat and Fluid Flow

View details of this citation

Inform me when this document is cited in Scopus:

Set citation alert >

\section{Related documents}

Impact of expansion level on flowfield with sudden expansion at supersonic regimes

Faheem, M. , Ridwan, Muneer, R. (2021) Materials Today: Proceedings

Experimental investigation of the effect of cross wire on the flow field of elliptic jet

Faheem, M. , Khan, A. , Kumar, R. (2021) International Journal of Heat and Fluid Flow

Effect of expansion level on the flow development with sudden expansion at high Mach numbers

Faheem, M. , Ridwan, Muneer, R. (2021) Materials Today: Proceedings

View all related documents based on references

Find more related documents in Scopus based on:

Authors > Keywords > 
1 Khan, A., Kumar, R.

Experimental study and passive control of overexpanded plug nozzle jet

(2018) Journal of Spacecraft and Rockets, 55 (3), pp. 776-782. Cited 8 times.

http://arc.aiaa.org/loi/js

doi: 10.2514/1.A34039

View at Publisher

2 Khan, A., Panthi, R., Kumar, R., Mohammed Ibrahim, S.

Experimental investigation of the effect of extended cowl on the flow field of planar plug nozzles

(2019) Aerospace Science and Technology, 88, pp. 208-221. Cited 12 times.

doi: 10.1016/j.ast.2019.03.011

View at Publisher

3 Khan, A., Akram, S., Kumar, R.

Experimental study on enhancement of supersonic twin-jet mixing by vortex generators

(2020) Aerospace Science and Technology, 96, art. no. 105521. Cited 16 times.

https://www.journals.elsevier.com/aerospace-science-and-technology.

doi: 10.1016/j.ast.2019.105521

View at Publisher

4 Panthi, R., Krishna, T.V., Nanda, S.R., Khan, A., Kumar, R., Sugarno, M.I.

Experimental study of impinging plug nozzle jet using a vortex generator

(2020) Journal of Spacecraft and Rockets, 57 (6), pp. 1414-1418. Cited 2 times.

http://arc.aiaa.org/loi/jsr

doi: $10.2514 / 1 . A 34760$

View at Publisher

5 Arun Kumar, P., Aileni, M., Rathakrishnan, E.

Impact of tab location relative to the nozzle exit on the shock structure of a supersonic jet

(2019) Physics of Fluids, 31 (7), art. no. 076104. Cited 13 times.

http://scitation.aip.org/content/aip/journal/pof2

doi: $10.1063 / 1.5111328$

View at Publisher

6 Arun Kumar, P., Rathakrishnan, E.

Corrugated right-angled triangular tabs for supersonic jet control

(2015) Proceedings of the Institution of Mechanical Engineers, Part G: Journal of Aerospace Engineering, 229 (11), pp. 2066-2084. Cited 5 times.

http://pig.sagepub.com/content/by/year

doi: 10.1177/0954410014564611

View at Publisher

7 Rathakrishnan, E.

Triangular tabs for supersonic jet mixing enhancement

(2014) Lecture Notes in Mechanical Engineering, 8, pp. 27-38. Cited 2 times.

www.springer.com/series/11236

doi: $10.1007 / 978-3-642-40371-2 \_3$

View at Publisher

8 Krothapalli, A., Rajkuperan, E., Alvi, F., Lourenco, L.

Flow field and noise characteristics of a supersonic impinging jet

(1999) Journal of Fluid Mechanics, 392, pp. 155-181. Cited 270 times.

http://journals.cambridge.org/action/displayjournal?jid=FLM

doi: $10.1017 / 50022112099005406$

View at Publisher 
$\square 9$ Samimy, M., Kim, J.-H., Kastner, J., Adamovich, I., Utkin, Y.

Active control of high-speed and high-Reynolds-number jets using plasma actuators

(2007) Journal of Fluid Mechanics, 578, pp. 305-330. Cited 308 times. doi: $10.1017 /$ S0022112007004867

View at Publisher

10 Rathakrishnan, E.

A numerical approach to single and twin supersonic jet flows (2004) IITK, 1, pp. 32-34.

11 Akram, S., Rathakrishnan, E.

Control of Supersonic Elliptic Jet with Ventilated Tabs

(2017) International Journal of Turbo and Jet Engines. Cited 4 times.

Walter de Gruyter GmbH, Sep. 26

12 Akram, S., Rathakrishnan, E.

Corrugated Tabs for Enhanced Mixing of Supersonic Elliptic Jet

(2019) Journal of Aerospace Engineering, 32 (1), art. no. 04018140. Cited 7 times.

http://ascelibrary.org/aso/resource/1/jaeeez

doi: 10.1061/(ASCE)AS.1943-5525.0000970

View at Publisher

13 Akram, S., Rathakrishnan, E.

Corrugated Tabs for Enhanced Mixing of Supersonic Elliptic Jet

(2019) Journal of Aerospace Engineering, 32 (1), art. no. 04018140. Cited 7 times.

http://ascelibrary.org/aso/resource/1/jaeeez

doi: 10.1061/(ASCE)AS.1943-5525.0000970

View at Publisher

14 Faheem, M., Khan, A., Kumar, R., Khan, S.A.

Experimental Study of Supersonic Multiple Jet Flow Field

(2019) 32nd International Symposium on ShockWaves (ISSW32), pp. 2725-2731. Cited 9

times.

15 Khan, A., Kumar, R., Verma, S.B., Manisankar, C.

Effect of cross wire tab orientation on twin jet mixing characteristics

(2018) Experimental Thermal and Fluid Science, 99, pp. 344-356. Cited 13 times. doi: 10.1016/j.expthermflusci.2018.08.005

View at Publisher

16 Faheem, M., Khan, A., Kumar, R., Afghan Khan, S., Asrar, W., Sapardi, A.M.

Experimental study on the mean flow characteristics of a supersonic multiple jet configuration (Open Access)

(2021) Aerospace Science and Technology, 108, art. no. 106377. Cited 7 times.

https://www.journals.elsevier.com/aerospace-science-and-technology

doi: $10.1016 /$ j.ast.2020.106377

View at Publisher

17 Gawehn, T., Gülhan, A., Al-Hasan, N.S., Schnerr, G.H.

Experimental and numerical analysis of the structure of pseudo-shock systems in laval nozzles with parallel side walls

(2010) Shock Waves, 20 (4), pp. 297-306. Cited 24 times. doi: 10.1007/s00193-010-0263-1

View at Publisher 
18 Sellam, M., Fournier, G., Chpoun, A., Reijasse, P.

Numerical investigation of overexpanded nozzle flows: Asymmetrical configuration and hysteresis phenomenon

(2014) Shock Waves, 24 (1), pp. 33-39. Cited 8 times.

doi: 10.1007/s00193-013-0458-3

View at Publisher

19 Chauhan, V., Kumar, S.M.A., Rathakrishnan, E.

Mixing characteristics of underexpanded elliptic sonic jets from orifice and nozzle

(2015) Journal of Propulsion and Power, 31 (2), pp. 496-504. Cited 18 times.

http://arc.aiaa.org/loi/jpp

doi: 10.2514/1.B35451

View at Publisher

Khan, S.A.; Department of Mechanical Engineering, Faculty of Engineering, International Islamic University Malaysia, Kuala Lumpur, Malaysia; email:sakhan@iium.edu.my

(C) Copyright 2021 Elsevier B.V., All rights reserved.

\section{About Scopus}

What is Scopus

Content coverage

Scopus blog

Scopus API

Privacy matters

\section{Language}

日本語に切り替える

切换到简体中文

切換到繁體中文

Русский язык

\section{Customer Service}

Help

Contact us

ELSEVIER Terms and conditions $\pi \quad$ Privacy policy $\pi$

Copyright (C) Elsevier B.V ז. All rights reserved. Scopus ${ }^{\circledR}$ is a registered trademark of Elsevier B.V.

We use cookies to help provide and enhance our service and tailor content. By continuing, you agree to the use of cookies. 